\title{
Is the Upper Echelons Perspective Relevant Outside the US? An Empirical Study of Executives' Impact on Firm Performance in the Global Context
}

\author{
Seung B. Bach \\ State University at Sacramento \\ Jai Joon "Jay" Lee \\ State University at Sacramento
}

Author's Note

Seung B. Bach, California State University at Sacramento, Sacramento, CA 95819 Jai Joon "Jay" Lee, California State University at Sacramento, Sacramento, CA 95819 Correspondence concerning this article should be directed to bachs@csus.edu and jlee@csus.edu

\begin{abstract}
This study extends our understanding of the executive characteristics-firm performance relationship beyond the North American context. We found that the executive's international experience was positively related to firm profitability, but not to firm growth in our global sample. We also found that executive tenure was negatively related, and executive age was positively related to firm growth, but not to firm profitability. Notably, many of these relationships were moderated by the national developmental context in which the firm was headquartered. These results have important implications for the upper echelons perspective, and practical implications for senior executive selection and development.
\end{abstract}

Keywords: Upper Echelons Perspective, Executive Characteristics, Firm Performance, National Development 


\section{Upper Echelons Perspective and Executives' Impact on Firm Performance}

Previous research has repeatedly shown that senior executives have an incremental, but systematic impact on firm performance through what has been called "the Upper Echelons Perspective" (UEP) (Hambrick \& Mason, 1984; Wang et al. 2016). Despite our tendency to attribute skills and effects of executive leaders that sometimes do not necessarily exist in real life (Meindel, Ehrlich \& Dukerich,, 1985), the preponderance of evidence suggests that executive leadership does matter. For example, it is now well established that senior executives can affect firm performance by scanning the environment well (Garg, Walters \& Priem, 2003), by developing organizational capabilities that yield competitive advantages (Montelegre, 2002; Rosenblum, 2000), by refocusing around core competencies (Bigley \& Wiersema, 2002), and by facilitating organizational learning (Vera \& Crosan, 2004).

Unfortunately, the large majority of this research has been conducted on senior executives among the North American firms (Canella, 2001). Indeed, Hambrick (2007) encouraged researchers to refine and further extend the upper echelons perspective into globally representative samples. There are a few exceptions to this North American bias, but these studies are often limited to a single country, such as Great Britain (e.g., Karami, Analoui \& Kakabadse, 2006), India (e.g., Yasser et al., 2017), Spain (e.g., Diaz- Fernandez et al., 2014), Turkey (e.g., Yamak \& Usdiken, 2006), and China (e.g., Wei, Lau, Young \& Wang, 2005). Consequently, it is still arguable as to whether the relationships previously discovered exist outside North America given the differing cultural values and institutional norms operating throughout the world (Peng, 2000). The purpose of this paper is to address this gap in the literature by further extending the upper echelons perspective from a North American focus to a globally- oriented one. Specifically, we seek to learn if insights about the executive characteristics-firm performance relationship gained from previous studies in North America are universal or not; and begin to advance our understanding of global strategic leadership (Boal \& Hooijberg, 2000; Petrick, Scherer, Brodzinski, Quinn \& Ainina, 1999).

\section{Theory Development}

There are a wide variety of executive characteristics explored in the literature. In this study, we examined three of the most promising characteristics. The three factors examined in this study are: (1) international experience, (2) job tenure, and (3) age of the senior-most executive for a globallyrepresentative sample of firms. We selected these characteristics since they have widely presented and empirically studied in the upper echelons perspectives studies (Hambrick \& Mason, 1984; Finkelstein \& Hambrick, 1997).

\section{International Experience and Firm Performance}

A senior executive's international experience is conceptualized as the extent of time spent or assigned to conduct business outside the one's country of origin (Carpenter, Sanders \& Gregersen, 2001; Daily, Certo \& Dalton, 2000). Not only do the executives gain a deeper understanding of other countries when conducting business in foreign locations, but they also begin to transcend their own native culture and develop a "global mindset" (Kedia \& Mukherji, 1999; Javidan \& Walker, 2013). In addition to an expanded awareness of cultural similarities and differences, the executives develop his or her conceptual skills and broaden their interpersonal networks that are so valuable when operating at a senior executive position.

Higher levels of a senior executive's international experience have found to be associated with 
reduced uncertainty in international operations (Sambharya, 1996), an enhanced ability to manage operations in different countries (Black, 1997), increased possibilities for international alliance success (Pansiri, 2005), and an improved likelihood of success with foreign market entry (Herrmann \& Datta, 2002).

Consequently, we would expect that higher levels of international experience would be associated with higher levels of overall firm performance and firm growth due to the global mindset and the extended set of skills afforded through foreign work assignments. More formally:

Hypothesis la: A senior executive's extent of international experience is positively related to firm profitability in an international context.

Hypothesis 1b: A senior executive's extent of international experience is positively related to firm growth in an international context.

\section{Executive Job Tenure and Firm Performance}

Several scholars have argued that an executive's tenure on the job affects his or her knowledge base as well as relative power (Wu et al., 2005). Some even argue for an executive's "life cycle" where the executive's latitude of action changes over time (Hambrick \& Fukutami, 1991). When the executive first starts out, theory and research within American samples have shown that executive power is constrained and strategic choices are more heavily scrutinized by outsiders and board members. Due to the complexity of strategic decision making, this thorough oversight and monitoring will most likely lead to better overall decisions (Hambrick et al., 1993).

Furthermore, opportunities for adaptive learning are limited because (1) a senior executive assumes office with a relatively fixed point of view that changes little over time, (2) organizational inertia limits the speed at which an organization can align itself with a new CEO's point of view, and (3) for any learning to occur, the external environment must be stable enough so that the cause-effect relationships that CEOs glean today remain relevant tomorrow.

As such, this logic suggests that early in the job, senior executives will lead more effectively than later on in the job when his or her power is more absolute and executive hubris is more likely due to previous successes (Hiller \& Hambrick, 2005). Interestingly, there is empirical support for the "stale in the saddle" syndrome (Miller, 1991). For example, Hambrick, Geletkanycz and Fredrickson (1993) found that a senior executive's job tenure was positively associated with pursuit of the status quo within large U.S. firms. On the other hand, Rajagopalan and Datta (1996) found that the senior executive's job tenure was negatively associated with U.S. firm's sales growth.

Similarly, Henderson, Miller and Hambrick (2006) found that the senior executive's job tenure was negatively associated with firm performance, particularly in dynamic industry contexts. In addition, the CEO-Top Management Team (TMT) interface was tested as the intervening mechanism, and CEO tenure indirectly influenced firm performance through its direct influences on TMT's risktaking propensity and the firm's pursuit of entrepreneurial iniatives (Simsek, 2007).

Generally speaking, these past literatures suggests that the senior executive's job tenure will be inversely related to firm performance and firm growth due to increases in the executive's power, discretion, and hubris, and over time. 
Hypothesis 2a: A senior executive's job tenure has a negative relationship with firm profitability in an international context. Hypothesis $2 b$ : A senior executive's job tenure has a negative relationship with firm growth in an international context.

\section{Executive Age and Firm Performance}

Previous research has argued for a relationship between senior executive age and firm performance. For example, Hambrick and Mason (1984) noted that older executives had less physical stamina, diminished ability to integrate information, and should be more committed to the status quo. Furthermore, Bantel and Jackson (1989) asserted that the technological knowledge of recently educated younger executives was often superior to older executives which could translate into higher levels of organizational performance.

Empirically, the inverse relationships between executive age and firm performance are well supported in the various industry context. First, Grimm and Smith (1991) found that younger executives did take more risks and were more willing to pursue innovative strategic initiatives in the U.S. railroad industry. Next, Hitt and Tyler (1991) found that younger American managers exhibited more willingness to take risks and that this influenced firm growth. Pegels and Yang (2000) also found that younger executives were more efficient than older executives in generating strategic assets. Additionally, Hermann (2002) found that executive age was inversely related with international diversification, which was a major contributor to firm growth.

As the above research suggests, executive age is expected to be inversely associated with firm growth due to the risks involved with this performance objective. On the other hand, Bantel and Jackson (1989) failed to find a systematic relationship between executive age and firm's innovativeness within the U.S. banking sector. Interestingly, however, there is very little empirical support for a relationship between executive age and firm profitability in the international context.

Hypothesis 3a: A senior executive's age is unrelated to firm profitability in an international context.

Hypothesis 3b: A senior executive's age is negatively related to firm growth in an international context.

\section{Moderating Effects of National Context}

Previous upper echelons research has pointed out that the environmental context influences the executive characteristics-firm performance relationship. Finkelstein and Hambrick (1997) argued that certain contexts provided more 'managerial discretion,' or latitude of action, than others; and hence, the upper echelons perspective was more relevant in "high discretion" contexts.

Subsequent research on North American executives has found some evidence supporting the notion that high discretion contexts provide a stronger relationship between executive compensation characteristics and firm performance (e.g., Finkelstein \& Boyd, 1998; Marin \& Sanchez, 2005) and also executive turnover (Shen $\&$ Cho, 2005). Notably, little research has found an impact of industry 
context on the characteristics-performance relationship (Rajagopalan \& Datta, 1996). Furthermore, there has not been a significant research examining the executive characteristics-firm performance relationship in an international context.

In the global economy, economic relationships are fundamentally different in developed versus developing economies (Peng, 2003). As a result, the national economic context in which these firms operate may moderate the executive characteristics-firm performance relationship. Also, there is an increasing support for the notion that national development influences firm performance. For example, Wyer and Mason (1998) demonstrated that small firm performance was influenced by the state of economic development offered within two developing economies (e.g., Malaysia and East Germany) as compared to that within a developed economy (e.g., United Kingdom).

Dollar and associates (2005) demonstrated that the firm performance was hindered by the adverse investment climates within developing economies. Specifically, they showed that the protracted customs delays, propensity to lose power, and extent of bureaucracy to obtain phone service limited firm growth in four different developing economies. And Gyimah-Brempong and GyimahBrempong (2006) examined a wide variety of nations and found a robust inverse relationship between economic development and the prevalence of corruption, suggesting that poverty made corruption more likely but it also hindered firm performance in developing nations. This theory and research suggest that the home country's state of economic development is likely to influence the executive's impact on firm performance due to its impact on managerial discretion. Unfortunately, there is insufficient theory and research to predict directional hypotheses; however, the following nondirectional relationships are suggested:

Hypothesis 4a: The relationship between the senior executive's characteristics and firm profitability is moderated by the home country's state of economic development.

Hypothesis 4b: The relationship between the senior executive's characteristics and firm growth is moderated by the home country's state of economic development.

\section{Methodology}

\section{Sample}

In order to examine and more globally representative set of executives and firms, we performed a quota sampling procedure. As can be seen from Exhibit 1, the top ten economies in 2005 are listed according to national wealth. That listing contains six developed economies and four developing economies, and it represents more than $\$ 36$ trillion USD (roughly $65 \%$ ) of the global economy.

Next, a ratio was calculated for each economy according to the relative size of that economy. For example, the U.S. economy was over $\$ 11$ trillion in 2005, so its share of the top ten's aggregate GDP was $38 \%$ of the total. This ratio was used to determine the number of firms that would be sampled from that particular country.

Continuing with the US. example, since it represented $38 \%$ of the collective wealth of the top ten economies, we strove to make $38 \%$ of our organizations to be based in the US. The same procedure was taken for each of the ten economies with a target sample of 121 firms. 
After that, we went to the Marquis Whose Who on-line database and quota sampled firms and executives based in each of the ten economies until we had the requisite number of complete records for this study. Consequently, we ended up with 121 firms in our final sample. This set of firms contained 49 manufacturing-based firms, 69 service-based firms, and 3 firms from which we could not identify the firm's primary industry. The manufacturing firms came various sectors such as food and beverage, technology and computer, chemical, metal, and automobile industries. The servicebased firms included financial, hospitality, real estate, construction, healthcare, utility, transportation, telecommunication and retail industries.

With respect to geographical representation, our sample was comprised of 38 firms based in the US, 24 firms located in China, 13 firms headquartered in Japan, 11 firms in India, 8 from Germany, 6 firms in the UK and France, and 5 firms based in Russia, Brazil and Italy.

As can be seen from Table 1, we were largely successful in generating a globallyrepresentative sample of firms. After identifying the firms, we collected additional data about the firm's senior-most executive, additional firm characteristics, and information about this firm's national economy to perform our study. The average age of the senior executives in our sample was 58.3 years, and their average firm and job tenures were 20.7 and 6.7 years, respectively. Their average international experience was 2.3 years in foreign assignments.

Table 1

Sampling Design for this Study

\begin{tabular}{|c|l|c|c|c|c|}
\hline Ranking & National Economy & $\begin{array}{c}\text { 2005 GDP } \\
\text { (Millions of USD) }\end{array}$ & $\begin{array}{l}\text { Proportio } \\
\text { n of Top } \\
\text { Ten GDP }\end{array}$ & $\begin{array}{l}\text { Number of } \\
\text { Firms } \\
\text { Sampled }\end{array}$ & $\begin{array}{c}\text { Proportion } \\
\text { of Overall } \\
\text { Sample }\end{array}$ \\
\hline 1 & United States & $\$ 11,605,185$ & $32 \%$ & 38 & $31 \%$ \\
\hline 2 & $\begin{array}{l}\text { People's Republic of } \\
\text { China }\end{array}$ & $\$ 7,334,254$ & $20 \%$ & 24 & $20 \%$ \\
\hline 3 & Japan & $\$ 3,817,221$ & $10 \%$ & 13 & $11 \%$ \\
\hline 4 & India & $\$ 3,290,800$ & $9 \%$ & 11 & $9 \%$ \\
\hline 5 & Germany & $\$ 2,391,569$ & $7 \%$ & 8 & $7 \%$ \\
\hline 6 & United Kingdom & $\$ 1,736,377$ & $5 \%$ & 6 & $5 \%$ \\
\hline 7 & France & $\$ 1,724,647$ & $5 \%$ & 6 & $5 \%$ \\
\hline 8 & Italy & $\$ 1,461,564$ & $4 \%$ & 5 & $4 \%$ \\
\hline 9 & Brazil & $\$ 1,449,170$ & $4 \%$ & 5 & $4 \%$ \\
\hline 10 & Russia & $\$ 36,431,241$ & $100 \%$ & 121 & $100 \%$ \\
\hline
\end{tabular}




\section{Variables and Measures}

Dependent variables. Smith and Tushman (2005) argued that strategic leaders must increasingly reconcile dilemmas and contradictions. In the area of firm performance, one key dilemma is whether to focus on firm profitability or firm growth. While both are required firm's sustainability, but each requires a different skill set of organizational skills and resources, and reconciling this dilemma is not easy. Perhaps this is why these two measures are arguably the two most common firm performance metrics in the UEP literature.

Thus, to be as comprehensive as possible, we explored two dependent measures in this study firm profitability and firm growth. The firm profitability measure was computed by averaging the return on equity and the return on assets for the firm for 2006. Both profitability measures were standardized to industry averages to facilitate relevant comparisons across industries (Christensen \& Montgomery, 1981; Dubovsky \& Varadarajan, 1987). This measure is a proxy for a firm's ability to efficiently exploit existing product-markets.

The firm growth measure was calculated by averaging the three annual percentage growth in revenue figures from 2003 until 2006. This data was obtained from the Thomson (2007) online database. The historical growth rate of revenues was used because it could be a critical indicator of a firm's ability to creatively explore new product-markets (Murray, Kotabe, \& Zhou, 2005). The threeyear period was used to minimize distortion from anomalous fluctuations of revenues in any one given year (Roth, 1992).

Independent variables. There were three independent variables explored in this study. The first executive characteristic explored was the international experience. Similar to Finkelstein and Hambrick (1997), this measure was calculated as the number of years that the executive had spent in work environments that were outside his home country. These data were obtained from the Marquis Whose Who (2006) database, and it represents data published in 2004 or 2005.

The second executive characteristic examined in this study was job tenure. Following Finkelstein and Hambrick (1997), this measure was simply the number of years that this senior executive had filled this particular senior position. This archival information was obtained from the Marquis Whose Who (2006) database, and it represents data published in 2004 or 2005.

The third executive characteristic we examined was the age of the executive. This measure was determined by obtaining the executive's birth year and subtracting it from 2006. We obtained this birth year data information from the Marquis Whose Who (2006) database, and once again, it represents data published in 2004 or 2005.

Control variables. We employed three control variables in this study. First, we controlled for organizational size due to its well established relationship with firm performance. We operationalized this measure as the number of employees working for the organization in question as of 2005. To reduce skewness, we took the log transformation of this measure. These data were obtained from the on-line Thomson (2006) database.

Our second control variable was industry sector. Specifically, we coded the firm as a "0" if its primary revenue source came from a service-based business and we 
coded it as a " 1 " if its primary revenue source came from a manufacturing-based business. We obtained this data from the online Thomson (2006) database.

Our third and final control variable was national economic development. It was also a dichotomous measure where "1" was coded for developing countries (e.g., Brazil, Russia, India, and China) and a "0" was coded for developed countries (e.g., United States, United Kingdom, Germany, France, Italy, and Japan). This variable also served as a moderating variable in our analysis.

\section{Results}

Table 2 contains our descriptive statistics for the variables in the study. Despite the relatively low levels of correlation between the independent variables, we tested for multicollinearity to make sure that the assumption of independent events is not violated. Based on variance inflation factor (VIF) analyses, we found little cause for concern.

Notably, the highest VIF score was 1.42 (without moderating terms) and 2.58 (with moderating terms), which is well within acceptable parameters (Peng \& Luo, 2000; Reuter \& Leiblein, 2000; Werner \& Lester, 2001).

Table 2

Descriptive Statistics and Correlations $(n=121)$

\begin{tabular}{|c|c|c|c|c|c|c|c|c|c|}
\hline & Mean & $\begin{array}{l}\text { Std. } \\
\text { Dev. }\end{array}$ & 1 & 2 & 3 & 4 & 5 & 6 & 7 \\
\hline 1. Firm Profitability & .00 & 1.00 & & & & & & & \\
\hline 2. Firm Growth & .17 & .30 & .16 & & & & & & \\
\hline 3. Firm Size (transformed) & 10.71 & 1.66 & .16 & $-.40^{* *}$ & & & & & \\
\hline 4. Primary Industry Sector & .58 & .49 & -.01 & -.13 & .04 & & & & \\
\hline 5. National Development ${ }^{\mathrm{b}}$ & .37 & .49 & .14 & $.37^{* *}$ & $-.45^{* *}$ & -.06 & & & \\
\hline $\begin{array}{l}\text { 6. Executive Int'l. } \\
\text { Experience }\end{array}$ & 2.28 & 6.07 & $.21^{*}$ & -.17 & .07 & $-.22^{*}$ & $-.19^{*}$ & & \\
\hline 7. Executive Job Tenure & 6.95 & 6.82 & .06 & -.00 & $-.26^{* *}$ & .06 & $.23^{* *}$ & -.09 & \\
\hline 8. Executive Age & 58.33 & 8.75 & .02 & -.02 & $.26^{* *}$ & .13 & -.15 & .04 & $.28^{* *}$ \\
\hline
\end{tabular}

$* \mathrm{p}<.05$

$* * \mathrm{p}<.01$

a Primary industry sector was coded as a " 0 " if in the manufacturing sector, and a " 1 " if in the service sector.

b National development was coded as a " 0 " if a developed nation, and a " 1 " if a developing nation.

To test our hypotheses, we first regressed our controls, then our independent effects and finally the moderation relationships against firm profitability, Table 3. As can be seen from Model 1 in Table 3, our "controls only" model was significant $(\mathrm{F}=2.21, \mathrm{p}<$ $.05)$ and it explained $8 \%$ of the variance in firm profitability. 
In Model 2 of Table 3, we added our three independent measures. This regression was marginally significant $(\mathrm{F}=2.19, \mathrm{p}<.05)$ and only our international experience hypothesis was supported $(t=2.35, \mathrm{p}<.05)$ as a predictor of firm profitability. Since we had hypothesized no relationship between executive age and firm profitability, H3a was also supported by our data.

In Model 3 of Table 3, we found relatively strong support for the moderating effect of national development on the relationships between executive characteristics and firm profitability $(\mathrm{F}=2.30, \mathrm{p}$ $<.05)$. Specifically, the effect of International Experience was significant at the presence of the moderating variable (International Experience $x$ Development: $t=2.24, p<.05$ ) and these relationships explained an additional $8 \%$ in organizational profitability. As a result, our data partially support for $\mathrm{H} 4 \mathrm{a}$.

Table 3

Regression Analysis on Firm Profitability $(\mathrm{n}=87)$

\begin{tabular}{|c|c|c|c|c|c|c|}
\hline \multirow[t]{2}{*}{ Variables } & \multicolumn{2}{|c|}{ Model 1} & \multicolumn{2}{|c|}{ Model 2} & \multicolumn{2}{|c|}{ Model 3} \\
\hline & Beta & T-value & Beta & T-value & Beta & T-value \\
\hline Constant & & $-2.31 *$ & & $-2.01 *$ & & -0.66 \\
\hline 1 Firm Size & .29 & $2.25^{*}$ & .33 & $2.53 * *$ & .30 & $2.31 *$ \\
\hline Industrial Sector & -.01 & -.06 & .06 & .50 & .05 & 0.44 \\
\hline National Development & .27 & $2.12 *$ & .31 & $2.40 * *$ & .37 & $2.92 * *$ \\
\hline 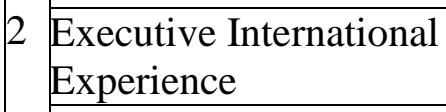 & & & .27 & $2.35 *$ & .15 & 1.20 \\
\hline Executive Job Tenure & & & .12 & 0.96 & .13 & 0.84 \\
\hline Executive Age & & & -.08 & -0.63 & -.22 & -1.30 \\
\hline & & & & M, & & \\
\hline & & & & & & \\
\hline $3 \begin{array}{l}\text { Experience } \mathrm{x} \\
\text { Development }\end{array}$ & & & & & .29 & $2.24 *$ \\
\hline Tenure x Development & & & & & -.12 & -0.73 \\
\hline Age x Development & & & & & .23 & 1.36 \\
\hline F-Value & $2.21 *$ & & $2.19 *$ & & $2.30^{*}$ & \\
\hline R-Squared & .08 & & .16 & & .24 & \\
\hline Adjusted R-Square & .05 & & .09 & & .14 & \\
\hline R Change & $.08 *$ & & $.08 *$ & & $.08 *$ & \\
\hline
\end{tabular}

$$
\begin{aligned}
& * \mathrm{p}<.05 \\
& * * \mathrm{p}<.01 \\
& * * * \mathrm{p}<.001
\end{aligned}
$$

We repeated this analysis for our second dependent variable, firm growth, in Table 4. As can be seen from Model 4 in Table 4, we first entered our control variables. This regression was highly significant $(\mathrm{F}=7.54, \mathrm{p}<.001)$ as our controls alone explained roughly $21 \%$ of firm growth measure. 
Once again, in Model 5 of Table 4, we next added our independent variables and this regression was significant $(\mathrm{F}=5.23, \mathrm{p}<.001)$.

Notably, these independent variables collectively explained an additional $6 \%$ of variance in firm growth, above and beyond our controls..

Specifically, we found a negatively relationship between job tenure and firm growth $(\mathrm{t}=-2.04$, $\mathrm{p}<.05$ ), so our data supports $\mathrm{H} 2 \mathrm{~b}$. Furthermore, we found a significant relationship between executive age and growth, but this relationship was positive which was counter to our hypothesis $(\mathrm{t}=1.88, \mathrm{p}<$ .05). Consequently, our data did not support our H3b hypothesis.

Table 4

Regression Analysis on Firm Growth $(\mathrm{n}=87)$

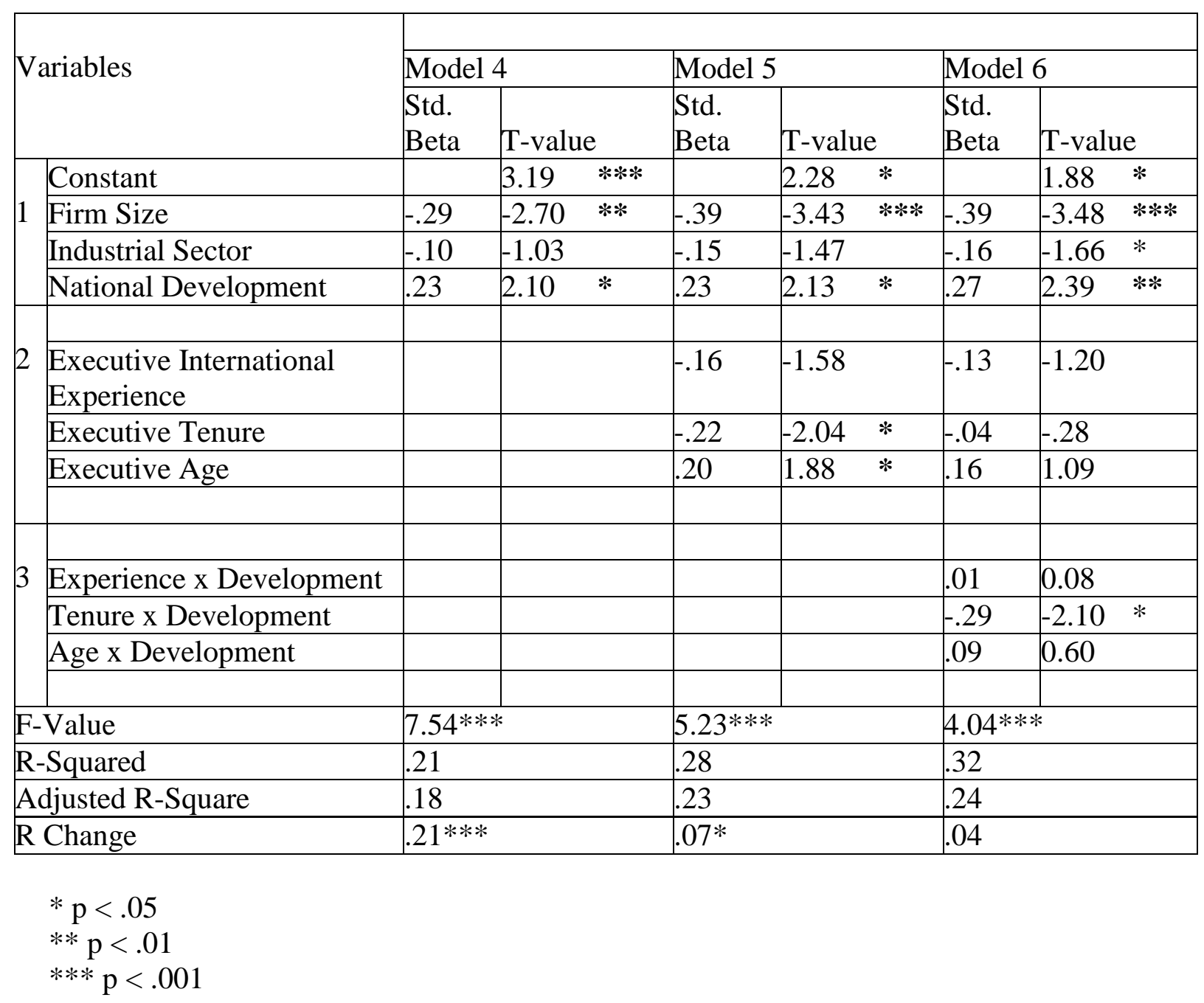

Finally, we explored the moderating effect of national development on the previously discussed relationships. The results of this moderated regression can be observed in Model 6 of Table 4. Once again, this regression was significant $(\mathrm{F}=4.04, \mathrm{p}<.001)$ and the moderating effects explained an 
additional $4 \%$ of variance in our dependent variable. Specifically, our significant main effects (Job Tenure) were even more significant when the moderation effects of national development were considered $(\mathrm{t}=-2.10, \mathrm{p}<.05)$. Consequently, we obtained partial empirical support for $\mathrm{H} 4 \mathrm{~b}$.

\section{Discussion and Future Research}

Table 5 contains a summary of the hypothesized relationships compared to our actual results. Clearly, our data provided general support for our hypotheses which was based largely on theory and research developed in the North American context.

Interestingly, however, our results varied considerably by the firm performance measures studied for our international sample. Specifically, we found that the primary executive-level predictor of firm profitability was the executive's level of international experience within an international context. As hypothesized, this relationship was positive and significant.

Table 5

Summary of Hypothesized Relationship and Actual Results

\begin{tabular}{|c|c|c|}
\hline Hypothes & Hypothesized Relationship & $\begin{array}{l}\text { Empirically } \\
\text { Supported? }\end{array}$ \\
\hline H1a & $\begin{array}{l}\text { The senior executive's international experience will be } \\
\text { positively associated } \\
\text { with organizational profitability in a global context }\end{array}$ & Yes \\
\hline $\mathrm{H} 1 \mathrm{~b}$ & $\begin{array}{l}\text { The senior executive's international experience will be } \\
\text { positively associated with organizational growth in a global } \\
\text { context }\end{array}$ & No \\
\hline $\mathrm{H} 2 \mathrm{a}$ & $\begin{array}{l}\text { The senior executive's job tenure will have a negative } \\
\text { relationship with organizational profitability in a global } \\
\text { context }\end{array}$ & No \\
\hline $\mathrm{H} 2 \mathrm{~b}$ & $\begin{array}{l}\text { The senior executive's job tenure will have a negative } \\
\text { relationship with organizational growth in a global context }\end{array}$ & Yes \\
\hline $\mathrm{H} 3 \mathrm{a}$ & $\begin{array}{l}\text { The senior executive's age will be unrelated to organizational } \\
\text { profitability in a } \\
\text { global context }\end{array}$ & Yes \\
\hline $\mathrm{H} 3 \mathrm{~b}$ & $\begin{array}{l}\text { The senior executive's age will be negatively related to } \\
\text { organizational growth } \\
\text { in a global context }\end{array}$ & $\begin{array}{l}\text { No } \\
\text { (positively related) }\end{array}$ \\
\hline $\mathrm{H} 4 \mathrm{a}$ & $\begin{array}{l}\text { The national level of development will moderate the } \\
\text { relationship between executive characteristics and } \\
\text { organizational profitability in a global context }\end{array}$ & $\begin{array}{l}\text { Partially } \\
\text { (international } \\
\text { experience) }\end{array}$ \\
\hline $\mathrm{H} 4 \mathrm{~b}$ & $\begin{array}{l}\text { The national level of development will moderate the } \\
\text { relationship between } \\
\text { executive characteristics and organizational growth in a global } \\
\text { context }\end{array}$ & $\begin{array}{l}\text { Partially } \\
\text { (executive age \& } \\
\text { tenure) }\end{array}$ \\
\hline
\end{tabular}


This finding is noteworthy, and provides practical career insight into what it takes to lead a large firm in any geographic context to higher levels of profitability. Evidently, there is no substitute for the learning derived from working overseas associates in foreign markets when it comes to being efficient and profitable. Furthermore, it appears that when the executives return to corporate headquarters, they provide the guidance and autonomy to allow business unit managers to become more profitable operations. Consequently, we believe that we have empirical support for the notion of so-called "global" managers who can bring their international experiences back to the entire corporation and leverage that knowledge (Pucik \& Saba, 1998).

Interestingly, the executive characteristics that influenced firm profitability were different from the characteristics that influenced firm growth. Our data revealed that job tenure was negatively associated with firm growth, but unrelated to firm profitability. This relationship was predicted by previous research and offers further support for Danny Miller's (1991) claim that senior executives can and often do get "stale in the saddle" within an international context, particularly with respect to firm profitability.

However, we found that executive age was positively associated with firm growth. This finding is counter to previous research in the North American samples where executive age has been found to be negatively related to firm growth (e.g., Grimm \& Smith, 1991; Hitt \& Tyler, 1991). This finding is interesting and important. It suggests that the "managerial wisdom" that comes with age is invaluable to guiding the firm to higher levels of growth (Boal \& Hooijberg, 2001) in an international context. In addition, it provides additional support to the recent research provided by Wei and associates (2005) regarding the positive impact of executive age on firm performance in China.

Finally, it appears that the macro-economic context of the firm's host country has a moderating influence on the executive characteristics-firm profitability relationship. Specifically, the senior executive's international experience-firm profitability relationship is more pronounced when the state of economic development surrounding the firm is considered carefully. In particular, international experiences of top executives in firm profitability appear to be more important in developing economies. This research offers empirical support for Carpenter's (2002) cogent argument that scholars interested in executives' impact need to study the national context in which these relationships occur. Furthermore, it suggests that future research needs to go beyond North American boundaries to really understand these relationships.

Also, the senior executive's tenure association with firm growth is stronger when one considers the developmental context, as hypothesized. Specifically, the negative association between the job tenure of executives and firm growth is less significant in developing economies than in developed economies. This result also suggests that future studies of strategic leadership should always consider the national context in which strategic leaders are examined. It also suggests that the institutional context of developing economies is fundamentally different from that within developed economies, lending support for Peng's (2000) argument that organizational scholars need to refine and extend their studies to a broader array of economic contexts.

While we have provided empirical support for some interesting and important relationships between executive characteristics and firm performance, these results must be treated with some caution. First, most of the firms examined in this study were relatively large in size. The average employment for the firms in our study was 114,023 . While there was an attempt to study the 
internationalization and firm performance of global Small and medium-sized enterprises (Hsu, Chen, \& Cheng, 2013), we simply need to know to what extent these findings are replicated among the smalland medium-sized firms in the global context. Second, the characteristics examined were limited to demographic proxies of senior executives' cognitions and skills. Future research clearly needs to examine these executive cognitions and skills more directly (Canella \& Monroe, 2003). Third, senior strategic leaders do not operate in a vacuum (Hambrick, 2007). Future research should examine the characteristics associated with top management teams to broaden our understanding of the leadership effect on firm performance. Finally, these associations are suggestive in nature due to the crosssectional nature of this sample. Future research needs to examine leads and lags associated with these relationships over time.

Despite these limitations, we have revealed some interesting preliminary relationships between senior executive characteristics and firm performance within a global context. Senior executives do appear to systematically influence firm performance in an international sample of relatively large firms, but their influence varies by developmental context within their home country and their impact varies by the performance metric considered. Notably, some relationships developed in a North American context applied to this international sample, while others did not.

In sum, it appears that senior executives do matter - even beyond their heavily- studied, highly individualistic North American context (Hofstede, 1999). Furthermore, we have shown that some of the relationships found in North American samples hold up in a global context (e.g. job tenure and international experience), while others do not (e.g., age). Finally, we have shown that the institutional context in which these executives operate can influence these relationships, as revealed by the developmental context in which the headquarter firm is located. Clearly, additional research is needed to refine and extend these findings. 


\section{References}

Bantel, K. \& Jackson, S. (1989). Top management and innovations in banking: Does the comp-osition of the top team make a difference? Strategic Management Journal, 10: 107-124.

Bigley, G., \& Wiersema, M. (2002). New CEOs and corporate strategic refocusing: How experience as heir apparent influences the use of power. Administrative Science Quarterly 47: 707-729.

Black, S. (1997). Top management team characteristics: A study of their impact on the magnitude of international operations and international performance. Unpublished doctoral dissertation. Columbia University, New York.

Boal, K., \& Hooijberg, R. (2001). Strategic leadership research: Moving on. Leadership Quarterly 11, 515-549.

Canella, B. 2001. Upper echelons: Donald Hambrick on executives and strategy. Academy of Management Executive, 15: 36-44.

Carpenter, M. 2002. The implications of strategy and social context for the relationship between top management team heterogeneity and firm performance. Strategic Management Journal, 23: 275291.

Carpenter, M., Sanders, G., \& Gregersen, H. 2001. Bundling Human Capital with Organizational Context: the Impact of International Assignment Experience on Multinational Firm Performance and CEO Pay. Academy of Management Journal, 44(3): 493-511.

Christensen, H. K., \& Montgomery, C. 1981. Corporate economic performance: Diversification strategy versus market structure. Strategic Management Journal, 2: 327-343.

Daily, C., Certo, S., \& Dalton, D. 2000. International Experience in the Executive Suite: the Path to Prosperity? Strategic Management Journal, 21(4): 515-523.

Diaz-Fernandez, M., Gonzalez-Rodriguez, M., \& Pawlak, M. 2014. Top Management Demographic Characteristics and Company Performance. Industrial Management \& Data Systems, 114 (3): $365-$ 386.

Dollar, D., Hallward-Driermeier, M., \& Megnistae, T., 2005. Investment climate and firm performance in developing economies. Economic Development and Cultural Change, 54: 1-31.

Dubovsky, P., \& Varadarajan, P. 1987. Diversification and measures of performance: Additional empirical evidence. Academy of Management Journal, 30: 597-608.

Elenkov, D., Judge, W., \& Wright, P., 2005. Strategic leadership and executive innovation influence: An international multi-cluster comparative study. Strategic Management Journal, 26: 665-682.

Finkelstein, S. \& Hambrick, D. 1997. Strategic leadership: Top executives and their effects on organizations. St. Paul, MN: West Publishing.

Finkelstein, S., \& Boyd, B. 1998. How much does the CEO matter? The role of managerial discretion in the setting of CEO compensation. Academy of Management Journal, 41: 179-200.

Garg, V, Walters, B., \& Priem, R. 2003. Chief executive scanning emphases, environmental dynamism, and manufacturing firm performance. Strategic Management Journal, 24: 725-744.

Glunk, U., Heijltjes, M., \& Olie, R. 2001. Design characteristics and functioning of top management teams in Europe. European Management Journal, 19:291-307.

Grimm, C., \& Smith, K. 1991. Management and organizational change: A note on the railroad industry. Strategic Management Journal, 12: 557-562.

Gyimah-Brempong, K., \& Giimah-Brempong, S. 2006. Corruption, growth, and income distribution: Are there regional differences? Economics of Governance, 7: 245 - 265.

Hambrick, D., \& Mason, P. 1984. Upper echelons: The organization as a reflection of its top managers. Academy of Management Review, 9: 193-206. 
Hambrick, D., \& Fukutomi, G. 1991. The seasons of a CEO's tenure. Academy of Management Review, 16: 719-742.

Hambrick, D., Geletkanycz, M., \& Fredrickson, J. 1993. Top executive commitment to the status quo: Some test of its determinants. Strategic Management Journal, 14: 401-418.

Hambrick, D. 2007. Upper echelons theory: An Update. Academy of Management Review, 32: 334343.

Hermann, P. 2002. The influence of CEO characteristics on the international diversification of manufacturing firms: An empirical study in the United States. International Journal of Management, 19:279-291.

Hiller, N., \& Hambrick, D. 2005. Conceptualizing executive hubris: The role of (hyper-) core self evaluations in strategic decision making. Strategic Management Journal, 26: 297-319.

Hofstede, G. 1999. Problems remain, but theories will change: the universal and specific in $21^{\text {st }}$ century global management. Organizational Dynamics, 28: 34-45.

Henderson, A., Miller, D., \& Hambrick, D. 2006. How quickly do CEOs become obsolete? Industry dynamism, CEO tenure, and company performance. Strategic Management Journal, 27: 447-467.

Herrmann, P., \& Datta, D. 2002. CEO successor characteristics and the choice of foreign market entry mode: An empirical study. Journal of International Business Studies, 33(3): 551-569.

Hitt, M., \& Tyler, B. 1991. Strategic decision models: Integrating different perspectives. Strategic Management Journal, 12: 327-351.

Hsu, W., Chen, H., \& Cheng, C. 2013. Internationalization and Firm Performance of SMEs: The Moderating Effects of CEO Attributes. Journal of World Business, 48: 1- 12.

Javidan, M., \& Walker, J. 2013. Developing Your Global Mindset: the Handbookfor Successful Global Leaders. Edina, MN: Beaver's Pond Press.

Karami, A., Analoui, F., \& Kakabadse, N. 2006. The CEOs' characteristics in their strategy development in the UK SME sector. Journal of Management Development, 25: 316-324.

Kedia, B., \& Mukherji, A. 1999. Global managers: Developing a mindset for global competitiveness. Journal of World Business, 34: 230-251.

Marquis Whose Who 2006. URL: http://www.marquiswhoswho.com/listees/default.asp.

Meindel, J., Ehrlich, S., \& Dukerich, J., 1985. The romance of leadership. Administrative Science Quarterly, 30: 78-102.

Miller, D. 1991. Stale in the saddle: CEO tenure and the match between organization and environment. Management Science, 37: 34-52.

Montealegre, R. 2002. A process model of capability development: lessons from the electronic commerce strategy at Bolsa de Valores de Guayaquil. Organization Science, 13: 514-531.

Murray, J., Kotabe, M., \& Zhou, J. 2005. Strategic alliance-based sourcing and market performance: Evidence from foreign operations in China. Journal of International Business Studies, 36: 187-208.

Pansiri, J. 2005. The influence of managers' characteristics and perceptions in strategic alliance practice. Management Decision, 43: 1097-1114.

Pegels, C., \& Yang, B. 2000. Top management team impact on strategic assets accumulation capabilities. Management Decision, 38: 694-715.

Peng, M. W., \& Luo, Y. 2000. Managerial ties and firm performance in atransition economy: The nature of a micro-macro link. Academy of Management Journal, 43(3): 486-501.

Peng, M. 2000. Business strategies in transition economies. Thousand Oaks, CA: Sage.

Petrick, J., Scherer, R., Brodzinski, J., quinn, J., \& Ainina, M. 1999. Global leadership skills and reputational capital: Intangible resources for sustainable competitive advantage. Academy of Management Executive, 13: 58-69.

Pucik, V., \& Saba, T. 1998. Selecting and developing the global versus the expatriate manager: A 
review of the state-of-the-art. Human Resource Planning. 21:40-55.

Rajagopalan, N., \& Datta, D., 1996. CEO characteristics: Does industry matter? Academy of Management Journal, 39(1): 197-215.

Rosenblum, R. 2000. Leadership, capabilities, and technological change: The transformation of NCR in the electronic era. Strategic Management Journal, 21: 1083-1103.

Roth, K. 1992. International configuration and coordination archetypes for medium- sized firms in global industries. Journal of International Business Studies, 23: 533- 549.

Sambharya, R. 1996. Foreign experience of top management teams and international diversification strategies of U.S. multinational corporations. Strategic Management Journal, 17, 739-746.

Shen, W., \& Cho, T. 2005. Exploring involuntary executive turnover through a managerial discretion framework. Academy of Management Review, 30: 843-863.

Simsek, Z. 2007. CEO Tenure and Organizational Performance: an Intervening Model. Strategic Management Journal, 28(6): 653-662.

Smith, W., \& Tushman, M. 2005. Managing strategic contradictions: A top management model for managing innovation streams. Organization Science, 16: 522-536.

Thomas, A., Lischert, R., \& Ramaswamy, K. 1991. The performance impact of strategy- manager coalignment: An empirical examination. Strategic Management Journal, 12: 509-522. Thomson Corporation, 2006. URL: http://www.thomson.com.

Vera, D., \& Crossan, M. 2004. Strategic leadership and organizational learning. Academy of Management Review, 29: 222-240.

Wang, G., Holmes Jr., R. M., Oh, I, \& Zhu, W. 2016. Do CEOs Matter to Firm Strategic Actions and Firm Performance? A Meta-Analytic Investigation Based on Upper Echolons Theory. Personnel Psychology, 69(4): 775-862.

Wei, L., Lau, C., Young, M., \& Wang, Z., 2005. The impact of top management team demography on firm performance in China. Asian Business \& Management, 4: 227- 239.

Werner, J. M., \& Lester, S. W. 2001. Applying a team effectiveness framework to the performance of students' case teams. Human Resource Development Quarterly, 12(4): 385-402.

Wu, S., Levitas, E., \& Priem, R. 2005. CEO tenure and company invention under differing levels of technological dynamism. Academy of Management Journal, 48(5): 859-873.

Wyer, P., \& Mason, J. 1998. An organizational learning perspective to enhancing understanding of people management in small business. International Journal of Entrepreneurial Behavior \& Research, 492: $112-128$.

Yamak, S., \& Usdiken, B., 2006. Economic liberalization and the antecedents of top management teams: Evidence from Turkish 'big' business. British Journal of Management, 17: 177-197.

Yasser, Q., Mamun, A., \& Rodrigs, M., 2017. Impact of Board Structure on Firm Performance: Evidence from an Emerging Economy. Journal of Asia Business Studies, 11(2): 210-228 